\title{
Using Artificial Neural Networks To Examine Semiotic Theories Of Accounting Accruals
}

\author{
Harlan L. Etheridge, (harlan@louisiana.edu), University of Louisiana at Lafayette \\ Kathy H. Y. Hsu, University of Louisiana at Lafayette
}

\begin{abstract}
Although the primary purpose of accounting is to communicate information, few studies have investigated the communicative nature of accounting. This study uses semiotics, a theory of signs and signals, to examine the purpose and usefulness of accounting accruals with a popular tool in forecasting--artificial neural networks. Two primary theories are proposed by this study. The Theory of the Functions of Accounting Accruals categories accounting accruals by their basic functions and states that two general types of accounting accruals exist: syntactic accruals and semantic accruals. Syntactic accounting accruals reflect incomplete transactions under a system of cash receipts and cash disbursements. Semantic accounting accruals present messages in a different format than their counterparts in a system of cash receipts and cash disbursements. The Theory of the Pragmatic Information of Accounting Accruals states that accounting accruals contain pragmatic information (value) because of their functions. The pragmatic information (value) of accounting accruals is examined by comparing the ability of accrual accounting data to forecast future cash flows compared to that of cash-flow accounting data. Forecasts are made using backpropagation neural networks. The results indicate that both syntactic and semantic accounting accruals contain pragmatic information (have value when forecasting future cash flows). The study provides evidence of the pragmatic information (value) of annual accounting accruals. However, no evidence was found in support of the pragmatic information (value) of quarterly accounting accruals. This result implies that annual accrual accounting data is a better predictor of future cash flows than cash-flow data while quarterly accrual accounting data is not.
\end{abstract}

\section{INTRODUCTION}

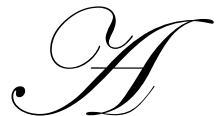

ccounting involves communication. Accountants communicate information in various ways including financial statements, auditor reports, and management reports. Despite the importance of the process of communication to accounting, accounting researchers have not focused on the development of formal theories of the accounting communicative process. However, the emphasis placed on the communication aspect of accounting by the Financial Accounting Standards Board suggests that more research into communication in the accounting process is desirable.

Because accounting may be categorized as a type of language (Kleerekoper 1963; Guthrie 1972; Jain 1973; Belkaoui 1980), examination of the communication features of accounting should be a part of the evolution of the accounting discipline. Theories that describe the accounting communicative process should foster refinement of the means of communication in accounting, namely, accounting reports and their components. Accounting accruals are one of the components of accounting reports that could be examined with communication theory.

The purpose of this study is to develop and test semiotic theories of accounting accruals. Semiotics encompasses syntactic information theory, semantic information theory, and pragmatic information theory ${ }^{1}$. This 
study uses concepts from syntactic information theory and semantic information theory to explain the functions of accounting accruals. Pragmatic information theory is used to define and examine the value of accounting accruals.

Two theories of accounting accruals form the core of this study. The Theory of the Functions of Accounting Accruals is induced from observation of accounting accruals and states that accounting accruals are either related to syntactics or semantics. Syntactic accounting accruals reflect incomplete transactions under a system of cash receipts and cash disbursements.

Semantic accounting accruals present messages in a different format than their counterparts in a system of cash receipts and cash disbursements. The Theory of the Pragmatic Information of Accounting Accruals states that accounting accruals contain pragmatic information (value) as a result of their functions.

Quarterly and annual cash-flow and accrual data are obtained from COMPUSTAT for the period 1986 through 1988 and provided to a backpropagation neural network to generate forecasts of cash flows from operations. The forecasted cash flows are used to calculate an error metric that functioned as a measure of pragmatic information. An estimated generalized least squares variant of the Bonferroni procedure is used to detect differences between means of error metrics and to test the research hypotheses. The results indicate that syntactic and semantic accounting accruals contain pragmatic information (value). Hypotheses tests, however, provide evidence that only annual accounting accruals contain pragmatic information. Hypotheses tests also indicate that no difference exists between the pragmatic information contained in syntactic accounting accruals and the pragmatic information contained in semantic accounting accruals.

The results of this study support the FASB position that accrual accounting data is more useful for certain decisions than cash-flow accounting data. In addition, the theories of this study may be used as a basis for future examinations of accrual accounting data.

The remainder of this paper consists of the following. Section I discusses the theory formulation. Section II is concerned with previous accounting research investigating the information content of cash flows and accruals and the syntactic and semantic information properties of accounting data. Section III involves hypothesis development and testing while Section IV presents the results of the hypothesis tests. Section V contains our conclusions including implications, limitations, and suggestions for future research.

\section{THEORY FORMULATION}

\section{Theory of the Functions of Accounting Accruals}

The theory of the functions of accounting accruals categorizes accounting accruals by their function and is induced from observation of accounting accruals. One type of accounting accrual reflects incomplete transactions under a system of cash receipts and cash disbursements. The function of these accruals is to convey data about economic events associated with incomplete cash transactions. For example, the amounts owed by customers for credit sales are not reflected in cash-flow accounting data. Accruals that reflect economic events not reported under cash-flow accounting ${ }^{2}$ are referred to as syntactic accruals. The rationale for this classification is that syntactics is related to the "surprise value" of information, and accruals that reflect economic events not reported under cash-flow accounting should contain "surprise value" relative to the associated cash-flow data.

The second type of accounting accrual presents messages in a different format than its counterpart in a system of cash receipts and cash disbursements. For example, under cash-flow accounting, the entire purchase price of equipment is treated as an expired cost in the period of the purchase. Accrual accounting, however, recognizes only a portion of the purchase price as an expired cost in the period of the purchase; the remainder of the price is treated as an unexpired cost because the firm is expected to receive future benefits from the equipment. Accruals that restate messages that may be unclear to accounting data users when signaled under a system of cash receipts and 
cash disbursements are referred to as semantic accruals. The rationale for this classification is that semantics is related to "meaning", and these accruals restate the cash-flow data so that it is more meaningful to users. The theory of the functions of accounting accruals states that accounting accruals are either related to the syntactics (surprise value) or semantics (meaning) of accounting data.

Because accounting artificially divides a firm's life into discrete reporting time periods, economic events that have not resulted in completed cash transactions at the end of a reporting period are not disclosed. The messages associated with these incomplete transactions are not reported (signaled) under a system of cash receipts and cash disbursements in the period associated with the economic messages. Consequently, periodic reporting under a system of cash receipts and cash disbursements introduces syntactic noise into financial reports because some of the economic messages are not disclosed (signaled).

Conceptually, syntactic accounting accruals are related to the syntactics ${ }^{3}$ of accounting because they convey signals to financial statement users that are not found in cash-flow accounting reports. In this case, noise is introduced into the financial reporting process by periodic reporting under a system of cash receipts and cash disbursements. Syntactic accruals are used to recover some of the information lost to syntactic noise.

Semantic accounting accruals provide signals of economic messages in different formats than the original signals. A system of cash receipts and cash disbursements may sometimes lead to a misinterpretation of the meaning of accounting signals. Examples of messages that may be misinterpreted under a system of cash receipts and cash disbursements include (1) the purchase of long-lived machinery and (2) prepayment of insurance. In both cases, a system of cash receipts and cash disbursements results in both items being reported as cash disbursements in the purchase period. In both situations, future economic benefits are expected to result from the transactions and, thus, the economic events impact several reporting periods, not just the current reporting period. A system of cash receipts and cash disbursements, however, treats these economic events as affecting only the current reporting period (discrete) and does not reflect the fact that these economic events affect future cash flows and future performance of the firm (are continuous) ${ }^{4}$. Thus, the users of financial statements may not interpret the messages signaled under a system of cash receipts and cash disbursements correctly. If the messages are misunderstood, semantic noise is present. Semantic accounting accruals provide the same message as their counterparts under a system of cash receipts and cash disbursements; however, the message is provided in a format that is more easily comprehended.

This research examines the pragmatic information of syntactic and semantic accounting accruals. The fact that syntactic and semantic information are subsets of pragmatic information (Cherry, 1978) makes these examinations possible.

\section{Theory of the Pragmatic Information of Accounting Accruals}

The theory of the pragmatic information of accounting accruals explains why accounting accruals contain pragmatic information (value). Three axioms are used to deduce the theory of the pragmatic information of accounting accruals:

Axiom 1: $\quad$ The prediction of future cash flows can be enhanced by adding syntactic accounting accruals to cash-flow data ${ }^{5}$.

Axiom 2: $\quad$ The prediction of future cash flows can be enhanced by adding semantic accounting accruals to cash-flow data.

Axiom 3: $\quad$ Data that enhances the prediction of future cash flows when added to cash-flow data contains pragmatic information ${ }^{6}$. 
The theory of the pragmatic information of accounting accruals states that syntactic and semantic accounting accruals have pragmatic information because accounting accruals enhance the prediction of future cash flows when added to cash-flow data.

Axiom 1 and Axiom 2 are derived from the Financial Accounting Standards Board's (FASB's) position in the Statement of Financial Accounting Concepts (SFAC) No. 1 that accounting accruals assist financial statement users in forecasting future cash flows. The FASB $(1978,21)$ states that investors' and creditors'

... interest in an enterprise's future cash flows and its ability to generate favorable cash flows leads primarily to an interest in information about its earnings rather than information directly about its cash flows. . . accrual accounting generally provides a better indication of enterprise performance than information about current cash receipts and payments.

Axiom 3 ensues from the FASB's position in SFAC No. 1 that data which enables financial statement users to forecast future cash flows is useful (provides pragmatic information) to investors and creditors. The FASB (1978, 17-19) notes that:

. . . financial reporting should provide information to help investors, creditors, and others assess the amounts, timing, and uncertainty of prospective cash inflows...

... Investors, creditors, and others need information to help them form rational expectations about ... prospective cash receipts and assess the risk that the amounts or timing of the receipts may differ from expectations.

SFAC No. 1 suggests that any data that can be used to construct forecasts of future cash flows which are more precise than forecasts produced with only cash-flow data contains pragmatic information. The theory of the pragmatic information of accounting accruals states that both syntactic and semantic accounting accruals combined with cash-flow data provide more precise estimation of future cash flows than only cash-flow data and, therefore, syntactic and semantic accounting accruals contain pragmatic information.

\section{PREVIOUS RESEARCH}

Several capital market studies (Ball and Brown 1968; Beaver and Dukes 1972; Patell and Kaplan 1977; Beaver et al. 1972; Rayburn 1986; Schaefer and Kennelley 1986; Wilson 1986; Bowen et al. 1987; Wilson 1987; Bernard and Stober 1989; and Livnat and Zarowin 1990), cash-flow forecasting studies (Bowen et al. 1986 and Greenberg et al. 1986) and financial failure studies (Largay and Stickney 1980; Casey and Bartczak 1985; Gentry et al. 1985a; Gentry et al. 1985b; Gentry et al. 1987; Gombola et al. 1987; Lau and Lau 1988; Ariz and Lawson 1989; and Bahnson and Bartley 1991) examined the information content of accrual accounting data versus cash flows or funds flows. However, these studies did not have the advantage of theory support ${ }^{7}$. Bedford (1965) commented that the controversy surrounding the benefits of accrual accounting data versus the benefits of cash-flow data would continue until a general theory of accruals was available. Bedford $(1965,29)$ asserted that ". . there appears to be no satisfactory explanation of the nature of the accrual concept, nor are sufficient reasons set forth explaining why it should be used ..." Research studies examining the "information content" of accrual accounting data and cash-flow accounting data exhibit mixed results, as indicated by Neill et al. (1991). The results of some of these study follow.

Schaefer and Kennelley (1986) found that accrual earnings possess information beyond that of cash flows. Rayburn (1986) determined that both operating cash flows and aggregate accruals contain information beyond that contained in the other. Bowen et al. (1986) discovered that cash flows contained information beyond accrual earnings in pooled cross-sectional examinations. However, the results of year-by-year examinations indicated that accrual earnings contain information beyond that of cash flows. The results of Wilson $(1986,1987)$ indicated that the cash flow components of accrual earnings possess information beyond that of accrual earnings. The accrual components of earnings also were found to contain information beyond that in earnings. Wilson (1986) also found 
that total accruals possess information beyond that of cash flows. Bernard and Stober (1989) determined that Wilson's (1987) results were not generalizable to other time periods and note that their results conflict with the contention that cash flows have a larger effect on stock prices than accruals.

Several accounting studies have examined the syntactic and semantic information properties of accounting data. Lev (1969) applied basic syntactic information theory concepts to differentiate between bankrupt and nonbankrupt firms and to determinate the accuracy of budgets. Lee and Bedford (1969) defined accounting classification and measurement in terms of syntactic information theory. Ronen and Falk (1973) examined whether the entropy measure suggested by Lev (1969) for the calculation of information loss from the aggregation of financial data reflected user-perceived information loss and user-perceived need for information. Abdel-khalik (1974) conducted a field study to determine if syntactic information theory concepts as extended by Lev (1969) were useful in the context of decisions based on accounting information. Babich (1975) compared syntactic information theory analysis of financial statements with ratio analysis. Belkaoui (1976) used syntactic information theory to discriminate between firms acquired by other companies and firms not acquired by other companies. Pendlebury (1980) used syntactic information theory to determine the best level of data aggregation for groups of companies. Nakano (1972) discussed the use of semantically redundant financial data (price-adjusted financial statements and physical and environmental data) to reduce the social loss from the use of historical cost financial statements. Haried (1972) investigated the semantic problems of external accounting communication. A process called semantic differentiation was used to locate the meaning of various accounting terms, e.g., asset, liability, depreciation, in semantic space ${ }^{8}$. Haried (1973) investigated whether certain accounting terms had similar meanings to different groups and whether synonymous accounting concepts had similar meanings. Lebar (1982) conducted a semantic analysis of the management analysis section of Form 10-K, the financial press release, and the president's letter in the annual report to determine if the language used in these items was consistent with the objectives of corporate disclosure 9 . Oliver (1974) used the semantic differential technique to determine if accounting concepts had different meanings to members of seven different professional groups ${ }^{10}$. Belkaoui (1980) used multidimensional scaling techniques to analyze the perceptual differences of accounting concepts (e.g., the entity assumption, the going concern assumption, the period assumption) across three groups affiliated with accounting: accounting academicians, public accountants, and accounting students. Houghton (1988) determined that Haried's (1972, 1973) sevendimensional structure was not appropriate for use with accounting data and that the three-dimensional structure of Osgood et al. (1957) was appropriate for use with Haried's (1973) data. Houghton also noted that the re-examination of Haried's (1973) data indicated that significant between-group and between-concept differences existed.

\section{TESTING THE THEORIES OF ACCOUNTING ACCRUALS}

The theory of the pragmatic information of accounting accruals relies on the theory of the functions of accounting accruals for the categorization of accounting accruals by function. Thus, direct testing of the theory of pragmatic information of accounting accruals results in indirect testing of the theory of the functions of accounting accruals and is the approach used in this study. Therefore, the research questions, research hypotheses, variables, research design, data manipulations, and statistical tests have designs based on the theory of the pragmatic information of accounting accruals.

\section{Research Questions}

The research questions addressed in this study are:

1. Do syntactic accounting accruals possess pragmatic information?

2. Do semantic accounting accruals possess pragmatic information?

3. Do syntactic accounting accruals possess a level of pragmatic information different from the level of pragmatic information possessed by semantic accounting accruals? 


\section{Independent Variables and the Research Design}

The research questions suggest the appropriate independent variables to be used in this study. Research questions 1,2, and 3 consider the pragmatic information of syntactic accounting accruals and semantic accounting accruals. Thus, data type must be an independent variable in this research. The categories of data type are cash and cash flows from operations (cash-flow data), cash-flow data plus syntactic accounting accruals, and cash-flow data plus semantic accounting accruals. In order to examine the pragmatic information of accounting accruals in the context of external financial reporting, financial statement time frame is used as an independent variable. The financial statement time frames used in this research are quarterly and annual ${ }^{11}$. The quarterly periods begin with the second quarter of 1987 and end with the fourth quarter of 1988 . The annual time period is the year $1988^{12}$. Thus, there are eight forecast periods, seven quarterly and one annual. To ensure that all twenty-four combinations of data type and forecast period were included in this study, a 3 X 8 factorial design is used (see Table 1).

Table 1: Population Error Metric Means $\mu_{\mathrm{Ij}}$ (1) With Numerical Estimates (2)

\begin{tabular}{|c|c|c|c|c|c|c|c|c|}
\hline \multirow[t]{3}{*}{ Data Type } & \multicolumn{8}{|c|}{ Forecast Period } \\
\hline & \multicolumn{7}{|c|}{ Quarterly } & Annual \\
\hline & $87-2$ & $87-3$ & $87-4$ & $88-1$ & $88-2$ & $88-3$ & $88-4$ & 1988 \\
\hline $\mathrm{CF}^{3}$ & $\begin{array}{l}\mu_{11} \\
.6952 \\
\end{array}$ & $\begin{array}{l}\mu_{12} \\
.6006 \\
\end{array}$ & $\begin{array}{l}\mu_{13} \\
.6609 \\
\end{array}$ & $\begin{array}{l}\mu_{14} \\
.8099 \\
\end{array}$ & $\begin{array}{l}\mu_{15} \\
.7137 \\
\end{array}$ & $\begin{array}{l}\mu_{16} \\
.6974 \\
\end{array}$ & $\begin{array}{l}\mu_{17} \\
.7012 \\
\end{array}$ & $\begin{array}{l}\mu_{18} \\
.6200 \\
\end{array}$ \\
\hline $\mathrm{CF}+\mathrm{SYN}^{4}$ & $\begin{array}{l}\mu_{21} \\
.5974\end{array}$ & $\begin{array}{l}\mu_{22} \\
.5947\end{array}$ & $\begin{array}{l}\mu_{23} \\
.6219\end{array}$ & $\begin{array}{l}\mu_{24} \\
.8391\end{array}$ & $\begin{array}{l}\mu_{25} \\
.6573\end{array}$ & $\begin{array}{l}\mu_{26} \\
.6590\end{array}$ & $\begin{array}{l}\mu_{27} \\
.7101\end{array}$ & $\begin{array}{l}\mu_{28} \\
.5295\end{array}$ \\
\hline $\mathrm{CF}+\mathrm{SEM}^{5}$ & $\begin{array}{l}\mu_{31} \\
.6567\end{array}$ & $\begin{array}{l}\mu_{32} \\
.6086 \\
\end{array}$ & $\begin{array}{l}\mu_{33} \\
.6689 \\
\end{array}$ & $\begin{array}{l}\mu_{34} \\
.8276 \\
\end{array}$ & $\begin{array}{l}\mu_{35} \\
.6928 \\
\end{array}$ & $\begin{array}{l}\mu_{36} \\
.6527\end{array}$ & $\begin{array}{l}\mu_{37} \\
.7080 \\
\end{array}$ & $\begin{array}{l}\mu_{38} \\
.5291 \\
\end{array}$ \\
\hline
\end{tabular}

\footnotetext{
$\mathrm{i}$ indexes Data Type and $\mathrm{j}$ indexes Forecast Period

Cash-flow data

4 Cash-flow data plus syntactic accounting accruals

5 Cash-flow data plus semantic accounting accruals
}

$\mu_{\mathrm{ij}}$ is estimated by the average of the error metrics for the 198 firms when Data Type $=\mathrm{i}$ and Forecast Period $=\mathrm{j}$

\section{Dependent Variables}

The pragmatic information of accounting accruals cannot be examined directly. The proxy that represents pragmatic information in this study is the enhancement of the precision of forecasts of cash flows from operations. This proxy is used because the FASB has indicated in SFAC No. 1 that data which enhances the accuracy of the prediction of future cash flows is useful to financial statement users. Consequently, data that facilitates the prediction of future cash flows has pragmatic information to financial statement users. By comparing the precision of cash-flow forecasts based on cash-flow data with the precision of cash-flow forecasts based on accounting accruals plus cash-flow data, the pragmatic information of accounting accruals can be determined. The ability to forecast future cash flows is measured with an error metric that is defined as the absolute value of the difference between the actual cash flow and the forecasted cash flow divided by the forecasted cash flow ${ }^{13}$ :

Both quarterly and annual accounting data can be used to forecast quarterly and annual cash flows. This research focuses on the qualities of quarterly accounting data that improve the forecasting of cash flows from operations one quarter into the future and the qualities of annual accounting data that improve the forecasting of cash flows from operations one year into the future. Thus the dependent variable for the quarterly financial statement time frame is cash flows from operations one quarter into the future and the dependent variable for the annual financial statement time frame is cash flows from operations one year into the future. 


\section{Research Hypotheses}

The FASB position in SFAC No. 1 is that accounting accruals have value (pragmatic information) in the prediction of future cash flows. This FASB position, together with research questions 1 and 2, leads to research hypotheses $\mathrm{H}_{\mathrm{a}} 1, \mathrm{H}_{\mathrm{a}} 1_{\mathrm{A}}, \mathrm{H}_{\mathrm{a}} 1_{\mathrm{Q}}, \mathrm{H}_{\mathrm{a}} 2, \mathrm{H}_{\mathrm{a}} 2_{\mathrm{A}}$, and $\mathrm{H}_{\mathrm{a}} 2_{\mathrm{Q}}$, stated below. Both the quarterly and annual error metrics are included in $\mathrm{H}_{\mathrm{a}} 1$ and $\mathrm{H}_{\mathrm{a}}$ 2, the primary research hypotheses. Only the quarterly error metrics are in the secondary research hypotheses $\mathrm{H}_{\mathrm{a}} 1_{\mathrm{Q}}$ and $\mathrm{H}_{\mathrm{a}} 2_{\mathrm{Q}}$. The secondary research hypotheses $\mathrm{H}_{\mathrm{a}} 1_{\mathrm{A}}$ and $\mathrm{H}_{\mathrm{a}} 2_{\mathrm{A}}$ contain only the annual error metrics.

$\mathbf{H}_{\mathbf{a}} \mathbf{1}$ : The error metric for cash-flow data plus syntactic accounting accruals will be smaller than the error metric for cash-flow only data.

$\mathbf{H}_{\mathbf{a}} \mathbf{1}_{\mathbf{A}}$ : Annual cash-flow data plus annual syntactic accounting accruals will have an error metric smaller than the error metric for annual cash-flow only data.

$\mathbf{H}_{\mathbf{a}} \mathbf{1}_{\mathbf{Q}}$ : Quarterly cash-flow data plus quarterly syntactic accounting accruals will have an error metric smaller than the error metric for quarterly cash-flow only data.

$\mathbf{H}_{\mathbf{a}}$ 2: $\quad$ The error metric for cash-flow data plus semantic accounting accruals will be smaller than the error metric for cash-flow only data.

$\mathbf{H}_{\mathbf{a}} \mathbf{2}_{\mathrm{A}}$ : Annual cash-flow data plus annual semantic accounting accruals will have an error metric smaller than the error metric for annual cash-flow only data.

$\mathbf{H}_{\mathbf{a}} \mathbf{2}_{\mathbf{Q}}$ : Quarterly cash-flow data plus quarterly semantic accounting accruals will have an error metric smaller than the error metric for quarterly cash-flow only data.

The theory of the pragmatic information of accounting accruals raises the question of how the pragmatic information of syntactic accounting accruals differs from the pragmatic information of semantic accounting accruals. The research hypotheses $\mathrm{H}_{\mathrm{a}} 3, \mathrm{H}_{\mathrm{a}} 3_{\mathrm{A}}$, and $\mathrm{H}_{\mathrm{a}} 3_{\mathrm{Q}}$, stated below, address the question of whether the pragmatic information of syntactic accounting accruals differs from the pragmatic information of semantic accounting accruals.

$\mathbf{H}_{\mathrm{a}}$ 3: $\quad$ The error metric for cash-flow data plus syntactic accounting accruals will be different from the error metric for cash-flow data plus semantic accounting accruals.

$\mathbf{H}_{\mathrm{a}} \mathbf{3}_{\mathrm{A}}$ : Annual cash-flow data plus annual syntactic accounting accruals will have an error metric different from the error metric for annual cash-flow data plus annual semantic accounting accruals.

$\mathbf{H}_{\mathbf{a}} \mathbf{3}_{\mathbf{Q}}$ : Quarterly cash-flow data plus quarterly syntactic accounting accruals will have an error metric different from the error metric for quarterly cash-flow data plus quarterly semantic accounting accruals.

Again, the primary research hypothesis $\mathrm{H}_{\mathrm{a}} 3$ contains both quarterly and annual error metrics, while the secondary research hypotheses $\mathrm{H}_{\mathrm{a}} 3_{\mathrm{A}}$ and $\mathrm{H}_{\mathrm{a}} 3_{\mathrm{Q}}$ contain only annual and quarterly error metrics, respectively.

\section{Sample Selection and Data Collection}

Quarterly and annual accounting data from the balance sheet ${ }^{14}$, income statement, and the statement of changes in financial position (SCFP) were obtained from COMPUSTAT for a sample of firms for the period 1986 through 1988. The sample includes all manufacturing firms (SIC codes 2000 to 3999) for which cash flows from operations $^{15}$, accrual components of earnings, and balance sheet data were available for the entire period under examination. 
The data items collected for the years 1986 through 1988 (including all quarters) include cash, cash flows from operations, and accounting accruals. In Table 2, these data items are listed and categorized into one of three data types: cash and cash flows from operations (cash-flow data), syntactic data, or semantic data. Accruals that signal messages not reported under a system of cash receipts and cash disbursements are classified as syntactic, while accruals that restate messages that are reported under a system of cash receipts and cash disbursements are classified as semantic.

Table 2: Grouping Of Data Items By Data Types

\begin{tabular}{l|l}
\hline \hline \multicolumn{1}{c|}{ Data Type } & \multicolumn{1}{c}{ Data Item } \\
\hline Cash-flow data & $\begin{array}{l}\text { Cash and short-term investments } \\
\text { Operating activities--net cash flow }\end{array}$ \\
\hline Syntactic data & $\begin{array}{l}\text { Receivables - total } \\
\text { Accounts payable and accrued liabilities } \\
\text { Income taxes payable } \\
\text { Equity in net loss (earnings) } \\
\text { Accounts receivable--decrease (increase) } \\
\text { Accounts payable and accrued liabilities--increase } \\
\text { (decrease) } \\
\text { Income taxes payable--increase (decrease) } \\
\text { Deferred taxes }\end{array}$ \\
\hline Semantic data & $\begin{array}{l}\text { Inventories-total } \\
\text { Debt in current liabilities } \\
\text { Inventories--decrease (increase) }\end{array}$ \\
& $\begin{array}{l}\text { Depreciation and amortization } \\
\text { Sale of property, plant and equipment and sale of } \\
\text { investments --loss (gain) }\end{array}$ \\
\hline $\begin{array}{l}\text { Certain disaggregated items, e.g., cash, accounts receivable--trade, and } \\
\text { inventory--finished goods, that are available on the annual tape are not } \\
\text { available on the quarterly tape. To ensure consistency between annual and }\end{array}$ \\
quarterly data, aggregated data items were collected for both annual and \\
quarterly time frames when disaggregated items were not available on the \\
quarterly tape. The level of aggregation used resulted in the mingling of \\
cash and accruals in some data items.
\end{tabular}

To ensure that missing data items would not influence the results of the study, firms missing any data items in the period of interest are eliminated from the sample. However, this restriction eliminated virtually every firm. Therefore, the missing data item restriction is relaxed by reducing the number of data items examined for missing or zero values $^{16}$. The new restriction results in a sample size of 214 firms. Examination of this sample discloses that data values of some firms were unrealistic ${ }^{17}$ and these firms are eliminated from the sample, providing a final sample of 198 firms. Many firms have zero values in sale of property, plant, and equipment and sale of investments--loss (gain) for all time periods of interest. Therefore, this data item is dropped. Both annual and quarterly data items for the final sample are validated with COMPACT DISCLOSURE.

\section{Forecasting Future Cash Flows}

An artificial neural network ${ }^{18}$ is used to structure the relationships between the independent and dependent variables, and to forecast cash flows. The artificial neural network software package used to forecast cash flows is NeuralWorks Professional II/Plus. Twenty-two artificial neural network paradigms are available on this software and eight, including back propagation ${ }^{19}$, are suitable for forecasting. Although artificial neural network literature describes back propagation as one of the best forecasting paradigms in neural computing, a comparison is made of the forecasting capabilities of the networks suitable for prediction. The networks are trained and tested with 1986 
annual cash-flow data. The sample is split into a training set of 150 firms and a test (holdback) set of 48 firms. The network performance test results indicate that the back propagation paradigm performed as well or better than other networks--see Table 3. Consequently, the back propagation paradigm ${ }^{20}$ is used for forecasting cash flows in this study.

Table 3: Artificial Neural Network Performance Test Results

\begin{tabular}{l|c|c|c}
\hline \hline \multicolumn{1}{c|}{ Network Paradigm } & $\begin{array}{c}\text { Pearson's R Coefficient -- } \\
\text { Training Data/ Test Data }\end{array}$ & $\begin{array}{c}\text { Root Mean } \\
\text { Squared Error }\end{array}$ & $\begin{array}{c}\text { Mean Error } \\
\text { Metric }\end{array}$ \\
\hline Backpropagation & $.9942 / .8899$ & .002 & .715249 \\
Backpropagation with functional link net sine inputs & $.9967 / .9130$ & .006 & .788276 \\
Delta-Bar-Delta & $.9878 / .8957$ & .004 & .715345 \\
Directed Random Search & $.9634 / .8809$ & .02 & .763797 \\
Extended Delta-Bar-Delta & $.7269 / .8751$ & .003 & .714100 \\
Kohonen self-organizing map into backpropagation & $.8578 / .8561$ & .0002 & 1.780147 \\
\hline
\end{tabular}

Quarterly and annual data from 1986 are used to train the artificial neural network in this study. Once training is completed, forecasts of cash flows from operations for quarterly and annual data are generated for all three data types. Quarterly forecasts are generated for the second quarter of 1987 through the fourth quarter of 1988, while an annual forecast is generated for 1988 .

\section{Hypothesis Tests}

All research hypotheses considered in this study may be stated succinctly in terms of contrasts (of population cell means). These population means are defined in Table 1. The estimates of these population means also appear in Table 1. Components of the contrasts are defined in Table 4. All null hypotheses appearing in this study are stated in terms of contrasts in Table 5. The numeric values for the associated test statistics also appear in Table 5 .

Let $Y_{\mathrm{ijk}}$ denote the error metric for the kth firm when data type = $\mathrm{i}$ and forecast period $=\mathrm{j}$ and let $\mathrm{L}$, which denotes any contrast in the population means of Table 4, be defined as:

$$
L=\sum_{i=1}^{3} \sum_{j=1}^{8} c_{i j} \mu_{i j} .
$$

Define the statistic W by:

$$
\mathrm{W}=\frac{\sum_{\mathrm{I}=1}^{3} \sum_{\mathrm{j}=1}^{8} \mathrm{c}_{\mathrm{ij}} \overline{Y_{\mathrm{ij}}}}{\sqrt{\frac{\mathrm{MSE} \sum_{\mathrm{i} j \mathrm{j}} \mathrm{c}_{\mathrm{ij}}^{2}}{198}}},
$$


where MSE denotes mean square error. Under the usual ANOVA assumptions, i.e., all $\mathrm{Y}_{\mathrm{ijk}}$ 's are independent and normally distributed with mean $\mu_{\mathrm{ij}}$ and (constant) variance $\sigma^{2}, \mathrm{H}_{\mathrm{o}}: \mathrm{L} \square 0\left(\mathrm{H}_{\mathrm{o}}: \mathrm{L}=0\right)$ is to be rejected in favor of $\mathrm{H}_{\mathrm{a}}: \mathrm{L}>0\left(\mathrm{H}_{\mathrm{a}}: \mathrm{L}=0\right)$ so that P(TYPE I) $\square .05$ if and only if the observed value of $\mathrm{W}(|\mathrm{W}|)$ exceeds $\mathrm{t}^{*}\left(\mathrm{t}^{* *}\right)$, where $\mathrm{t}^{*}\left(\mathrm{t}^{* *}\right)$ is the 95 th $(97.5$ th) percentile of the $\mathrm{t}$ distribution with 4728 degrees of freedom (Kirk 1982).

Table 4: Components For Contrasts Of Interest

\begin{tabular}{l|c}
\hline \hline \multicolumn{1}{c|}{ Linear Combination of Population Means } & \\
\hline Quarterly cash-flow data: $\left(\mu_{11}+\mu_{12}+\ldots+\mu_{17}\right) / 7$ & Symbol \\
Annual cash-flow data: $\mu_{18}$ & $\tau_{1}$ \\
Quarterly and annual cash-flow data: $\left(\tau_{1}+\tau_{2}\right) / 2$ & $\tau_{2}$ \\
Quarterly cash-flow plus syntactic data: $\left(\mu_{21}+\mu_{22}+\ldots+\mu_{27}\right) / 7$ & $\tau_{3}$ \\
Annual cash-flow plus syntactic data: $\mu_{28}$ & $\tau_{4}$ \\
Quarterly and annual cash-flow plus syntactic data: $\left(\tau_{4}+\tau_{5}\right) / 2$ & $\tau_{5}$ \\
Quarterly cash-flow plus semantic data: $\left(\mu_{31}+\mu_{32}+\ldots+\mu_{37}\right) / 7$ & $\tau_{6}$ \\
Annual cash-flow plus semantic data: $\mu_{38}$ & $\tau_{7}$ \\
Quarterly and annual cash-flow plus semantic data: $\left(\tau_{7}+\tau_{8}\right) / 2$ & $\tau_{8}$ \\
\hline
\end{tabular}

${ }^{1} \sum \sum \mathrm{c}_{\mathrm{ij}} \mu_{\mathrm{ij}}$ is estimated by ${ }_{\mathrm{ij}} \sum \mathrm{c}_{\mathrm{ij}} \mu_{\mathrm{ij}}$, where $\mu_{\mathrm{ij}}$ is the estimator of $\mu_{\mathrm{ij}}$ from Table 1 .

Table 5: Contrasts And Test Statistics

\begin{tabular}{l|c|c}
\hline \multicolumn{1}{c|}{ Null Hypothesis } & Contrast & Test Statistic - Numeric Value \\
\hline $\mathrm{H}_{\mathrm{o}} 1: \mathrm{L}=0$ & $\mathrm{~L}=\tau_{3}-\tau_{6}$ & $5.8280^{*}$ \\
$\mathrm{H}_{\mathrm{o}} 1_{\mathrm{A}}: \mathrm{L}=0$ & $\mathrm{~L}=\tau_{2}-\tau_{5}$ & $4.8141^{*}$ \\
$\mathrm{H}_{\mathrm{o}} 1_{\mathrm{Q}}: \mathrm{L}=0$ & $\mathrm{~L}=\tau_{1}-\tau_{4}$ & $2.1880^{* *}$ \\
$\mathrm{H}_{\mathrm{o}} 2: \mathrm{L}=0$ & $\mathrm{~L}=\tau_{3}-\tau_{9}$ & $4.3998^{*}$ \\
$\mathrm{H}_{\mathrm{o}} 2_{\mathrm{A}}: \mathrm{L}=0$ & $\mathrm{~L}=\tau_{2}-\tau_{8}$ & $5.0885^{*}$ \\
$\mathrm{H}_{\mathrm{o}} 2_{\mathrm{Q}}: \mathrm{L}=0$ & $\mathrm{~L}=\tau_{1}-\tau_{7}$ & $0.7267^{* *}$ \\
$\mathrm{H}_{\mathrm{o}} 3: \mathrm{L}=0$ & $\mathrm{~L}=\tau_{9}-\tau_{6}$ & $-0.9785^{* *}$ \\
$\mathrm{H}_{\mathrm{o}} 3_{\mathrm{A}}: \mathrm{L}=0$ & $\mathrm{~L}=\tau_{8}-\tau_{5}$ & $0.0171^{* *}$ \\
$\mathrm{H}_{\mathrm{o}} 3_{\mathrm{Q}}: \mathrm{L}=0$ & $\mathrm{~L}=\tau_{7}-\tau_{4}$ & $-2.4941^{* *}$ \\
\hline
\end{tabular}

* Significant at $\alpha=.01$.

${ }^{* * *}$ Not significant.

In vector notation, the statistic $\mathrm{W}$ may be written as:

$$
\mathrm{W}=\frac{\mathrm{c}^{\prime} \hat{\mu}}{\sqrt{\frac{\mathrm{c}^{\prime} \mathrm{MSEc}}{198}}},
$$

where $\mathbf{c}$ is the column vector of coefficients and $\mu$ is the column vector of estimated means, i.e., the $Y_{\mathrm{ij}}$ 's. Since observations within a firm cannot be assumed to be independent or to possess homogeneous variances, W must be modified. Assuming independence between firms, the modification is accomplished by replacing MSE with D, the variance/covariance matrix for a vector of observations for a firm. The new statistic is: 


$$
\mathrm{W}^{\prime}=\frac{\mathrm{c}^{\prime} \hat{\mu}}{\sqrt{\frac{\mathrm{c}^{\prime} \mathrm{D} \mathrm{c}}{198}}}
$$

The W' test statistic is a generalized least squares (GLS) modification of the W test statistic. However, GLS requires knowledge of the variance/covariance matrix D. Since the variance/covariance matrix $\mathrm{D}$ is unknown, it must be estimated from the data. The estimated variance/covariance matrix, D, results in a new test statistic, W":

$$
\mathrm{W}^{\prime \prime}=\frac{\mathrm{c}^{\prime} \hat{\mu}}{\sqrt{\frac{\mathrm{c}^{\prime} \hat{\mathrm{D}} \mathrm{c}}{198}}}
$$

When GLS is used with the estimated variance/covariance matrix instead of the actual variance/covariance matrix, the resulting technique is known as estimated generalized least squares (EGLS) ${ }^{21}$. Critical values for the W" test statistic are obtained from the standard normal distribution, since $\mathrm{W}^{\prime \prime}$ is asymptotically normal with mean 0 and variance $1^{22}$.

When several hypotheses are to be tested instead of just one, as in this study, the Bonferroni procedure ${ }^{23}$ may be used to control the overall Type I error rate for all hypotheses simultaneously, i.e., the probability of rejecting at least one null hypothesis when, in fact, all nulls are true. According to the Bonferroni procedure, if $\mathrm{m}$ null hypotheses are to be tested so that the overall Type I error rate for all hypotheses is to be controlled at the $\alpha^{\prime}$ level, then each should be tested individually with a Type I error rate of $\alpha=\alpha^{\prime} / \mathrm{m}$ (Neter and Wasserman 1974, 146, 480).

Since each of the three research questions gives rise to one primary and two secondary research hypotheses (for a total of three for each and nine altogether), each of the nine should be tested at the $\alpha=\alpha^{\prime} / 9$ in order to have overall protection of $\alpha^{\prime}$ for all nine simultaneously. Thus, when $\alpha^{\prime}=.05, \alpha=.05 / 9=.00555555 \ldots$, and when $\alpha^{\prime}=$ $.01, \alpha=.01 / 9=.00111111 \ldots$. Testing hypotheses 1 and 2 requires the use of a one-tailed test, while testing hypothesis 3 requires the use of a two-tailed test. The critical values for both one-tailed tests and two-tailed tests at overall $\alpha^{\prime}=.10$, overall $\alpha^{\prime}=.05$, and overall $\alpha^{\prime}=.01$ are listed in Table 6. The SAS procedure CORR was used to calculate the estimates of the error metric means appearing in Table 1, as well as the estimated variance/covariance matrix D used in the test statistics W". The IML procedure in SAS was used to calculate the numeric values of the test statistics which appear in Table 5.

Table 6: Critical Values For Hypothesis Tests

\begin{tabular}{l|l|l|c|c|c}
\hline \hline \multicolumn{3}{c|}{ One-Tailed Tests } & \multicolumn{3}{c}{ Two-Tailed Tests } \\
\hline$\alpha^{\prime}=. \mathbf{1 0}$ & $\alpha^{\prime}=. \mathbf{0 5}$ & $\alpha^{\prime}=. \mathbf{0 1}$ & $\alpha^{\prime}=. \mathbf{1 0}$ & $\alpha^{\prime}=. \mathbf{0 5}$ & $\boldsymbol{\alpha}^{\prime}=. \mathbf{0 1}$ \\
\hline 2.29 & 2.64 & 3.06 & 2.54 & 2.77 & 3.26 \\
\hline
\end{tabular}

\section{RESULTS OF HYPOTHESIS TESTS}

The hypothesis tests provide strong evidence against $\mathrm{H}_{0} 1$ and $\mathrm{H}_{0} 2$ indicating that both syntactic and semantic accounting accruals possess pragmatic information. This result also provides direct support for the theory of the pragmatic information of accounting accruals and indirect support for the theory of the functions of accounting accruals. The hypothesis tests provide strong evidence against $\mathrm{H}_{\mathrm{o}} 1_{\mathrm{A}}$ and $\mathrm{H}_{\mathrm{o}} 2_{\mathrm{A}}$ indicating that both syntactic and 
semantic accounting accruals contain pragmatic information in annual financial statements. The results, however, generate no evidence against $\mathrm{H}_{\mathrm{o}} 1_{\mathrm{Q}}$ and $\mathrm{H}_{\mathrm{o}} 2_{\mathrm{Q}}$ which suggests that neither syntactic nor semantic accruals contain pragmatic information in quarterly financial statements.

The hypothesis tests provide no evidence against $\mathrm{H}_{0} 3, \mathrm{H}_{0} 3_{\mathrm{A}}$, or $\mathrm{H}_{\mathrm{o}} 3_{\mathrm{Q}}$ which suggests that no difference exists between the amount of pragmatic information in syntactic accounting accruals and semantic accounting accruals of annual and quarterly financial statements, when considered separately or in combination.

\section{CONCLUSIONS}

\section{Implications}

The primary contribution of this study is the provision of two general theories of accounting accruals: the theory of the functions of accounting accruals and the theory of the pragmatic information of accounting accruals. This study provides direct evidence supporting the theory of the pragmatic information of accounting accruals and indirect evidence supporting the theory of the functions of accounting accruals. These theories can be used as a framework in future research investigating accounting accruals, and can assist other researchers in supporting the results of their studies.

This study provides evidence of pragmatic information of annual accounting accruals. No evidence is found in support of pragmatic information of quarterly accounting accruals. This result implies that annual accrual accounting data is a better predictor of future cash flows from operations than cash-flow data while quarterly accrual accounting data is not. One possible explanation is that quarterly accrual accounting data is significantly noisier that annual accrual accounting data. If quarterly accrual accounting data contains a significant amount of noise, the relationship between the accrual accounting data and future cash flows may be obscured. Consequently, forecasts of future cash flows based on quarterly accrual accounting data may be no better or even inferior compared to those based on quarterly cash-flow accounting data.

Another explanation for the difference in the incremental pragmatic information of annual and quarterly accrual data over cash-flow accounting data is related to audits. Quarterly financial statements are never audited while annual financial statements usually are ${ }^{24}$. Audits may enhance the reliability of annual accounting data compared to the reliability of quarterly accounting data. Reliable accrual data should have greater capacity to enhance the prediction of future cash flows than unreliable ${ }^{25}$ accrual data because reliable accrual data effectively discloses economic events that result in future cash inflows and outflows whereas unreliable accrual data does not. Research investigating the value of audits is needed to clarify this situation. If the reliability of accounting data is enhanced by audits, the need for audits of quarterly financial statements is suggested (subject to the cost-benefit principle).

Another possibility for the difference between the pragmatic information of annual and quarterly accounting accruals is that managers use accruals to smooth quarterly income. Managers may not smooth annual income to the extent that they smooth quarterly income because of audits. Consequently, annual accounting data may be more reliable $^{26}$ than quarterly accounting data. Evidence indicating restriction of managerial income smoothing would further support the value of audits. Additional research is needed to investigate this area.

This study used artificial neural networks as a methodological tool. Research in accounting and other disciplines has shown that artificial neural networks are a useful data analysis technique. This study is one of the first in accounting research to use artificial neural networks to forecast the values of accounting data. Artificial neural networks comprise a new and powerful data analysis technique for accounting research and may enhance the ability to investigate complex research questions. 


\section{REFERENCES}

1 Abdel-khalik, A. R. 1974. "The Entropy Law, Accounting Data, and Relevance to Decision-Making." The Accounting Review (April): 271-283.

2 Ariz, A. and G. Lawson. 1989. "Cash Flow Reporting and Financial Distress Models: Testing Hypotheses." Financial Management (Spring): 55-63.

3 Babich, G. 1975. "The Application of Information Theory to Accounting Reports: An Appraisal." Abacus (December): 172-181.

$4 \quad$ Bahnson, P. R., and J. W. Bartley. 1991. "Cash Flows and Financial Distress: Further Evidence." Working Paper, University of Montana.

$5 \quad$ Ball, R., and P. Brown. 1968. "An Empirical Evaluation of Accounting Income Numbers." Journal of Accounting Research (Autumn): 159-77.

6 Beaver, W. H., and R. E. Dukes. 1972. "Interperiod Tax Allocation, Earnings Expectations, and the Behavior of Security Prices." The Accounting Review (April): 320-32.

P. A. Griffin, and W. R. Landsman. 1982. "The Incremental Information Content of Replacement Cost Earnings.” Journal of Accounting and Economics (July): 15-39.

Bedford, N. M. 1965. "The Need for an Extension Of the Accrual Concept." The Journal of Accountancy (May): 29-33.

9 Belkaoui, A. 1980. "The Interprofessional Linguistic Communication of Accounting Concepts: An Experiment in Sociolinguistics." Journal of Accounting Research (Autumn): 362-374.

10 Bernard, V. L., and T. L. Stober. 1989. "The Nature and Amount of Information in Cash Flows and Accruals." The Accounting Review (October): 624-52.

11 Bowen, R. M., D. Burgstahler, and L. A. Daley. 1986. "Evidence on the Relationships Between Earnings and Various Measures of Cash Flow." The Accounting Review (October): 713-25. , D. Burgstahler, and L. A. Daley. 1987. "The Incremental Information Content of Accrual Versus Cash Flows." The Accounting Review (October): 723-47.

13 Brown, L. D., R. L. Hagerman, P. A. Griffin, and M. E. Zmijewski. 1987. "Security Analyst Superiority Relative to Univariate Time-Series Models in Forecasting Quarterly Earnings.” Journal of Accounting and Economics (April): 61-87.

14 Casey, C. J. and N. J. Bartczak. 1984. "Cash flow-It's Not the Bottom Line." Harvard Business Review (July/August): 61-66.

Casey, C. J. and N. J. Bartczak. 1985. "Using Operating Cash Flow Data to Predict Financial Distress: Some Extensions." Journal of Accounting Research (Spring): 384-401.

16 Cherry, C. 1978. On Human Communication. 3rd ed. Cambridge, MA: The MIT Press.

17 Etheridge, H. L., R. S. Sriram, and K. H. Y. Hsu. 2000. "A Comparison of Selected Artificial Neural Networks to Help Auditors Evaluate Client Financial Viability.” Decision Sciences. Vol. 31, No. 2, pp. 531 550

Fawcett, J., and F. S. Downs. 1986. The Relationship of Theory and Research. Norwalk, CT: AppletonCentury-Crofts.

19 FASB. 1978. Statement of Financial Accounting Concepts No. 1: Objectives of Financial Reporting by Business Enterprises. Norwalk, CT: FASB.

20 Gentry, J. A., P. Newbold, and D. T. Whitford. 1985a. "Classifying Bankrupt Firms with Funds Flow Components." Journal of Accounting Research (Spring): 146-60. , P. Newbold, and D. T. Whitford. 1985b. "Predicting Bankruptcy: If Cash Flow's Not the Bottom Line, What Is?" Financial Analysts Journal (September/October): 47-56. P. Newbold, and D. T. Whitford. 1987. "Funds Flow Components, Financial Ratios, and Bankruptcy." Journal of Business Finance and Accounting (Winter): 595-606.

Gombola, M. J., M. E. Haskins, J. E. Ketz, and D. D. Williams. 1987. "Cash Flow in Bankruptcy Prediction." Financial Management (Winter): 55-65.

24 Greenberg, R. R., G. L. Johnson, and K. Ramesh. 1986. "Earnings Versus Cash Flow as a Predictor of Future Cash Flow Measures.” Journal of Accounting, Auditing, and Finance (Fall): 266-77. 
25 Guthrie, A. 1972. "Modern Semantics Can Help Accounting.” The Journal of Accountancy (June): 56-63.

26 Haried, A. A. 1972. "The Semantic Dimensions of Financial Statements." Journal of Accounting Research (Autumn): 376-391. 1973. "Measurement of Meaning in Financial Reports." Journal of Accounting Research (Spring): 117-145. Hassell, J. M., and R. H. Jennings. 1986. "Relative Forecast Accuracy and the Timing of Earnings Forecast Announcements." The Accounting Review (January): 58-75.

29 Houghton, K. A. 1988. "The Measurement of Meaning in Accounting: A Critical Analysis of the Principal Evidence." Accounting, Organizations and Society (vol. 13. no. 3): 263-280.

30 Hyvärinen, L. P. 1968. Information Theory for Systems Engineers Lecture Notes in Operations Research and Mathematical Economics. ed. M. Beckmann and H. P. Künzi. Berlin: Springer-Verlag.

31 Jain, T. N. 1973. "Alternative Methods of Accounting and Decision Making: A Psycho-Linguistical Analysis." The Accounting Review (January): 95-104.

32 Judge, G., W. Griffiths, R. Hill, et al. 1985. The Theory and Practice of Econometrics. 2nd ed. New York: John Wiley and Sons.

33 Kirk, R. E. 1982. Experimental Design: Procedures for the Behavioral Sciences. Monterey, CA: Brooks/Cole Publishing Company.

34 Kleerekoper, I. 1963. "The Economic Approach to Accounting." The Journal of Accountancy (March): 3640.

Largay, J. A., and C. P. Stickney. 1980. "Cash Flows, Ratio Analysis and the W. T. Grant Bankruptcy." Financial Analysts Journal (July/August): 50-54.

Lau, A. H., and H. Lau. 1988. "Cash-flow Variables as Predictors of Financial Distress." Working paper, Oklahoma State University.

Lebar, M. A. 1982. "A General Semantics Analysis of Selected Sections of the 10-K, the Annual Report to Shareholders, and the Financial Press Release.” The Accounting Review. (January): 176-189. Accounting Review (April): 256-275. Lev, B. 1969. Accounting \& Information Theory Studies in Accounting Research \# 2. Sarasota, FL: American Accounting Association.

40 Livnat, J., and P. Zarowin. 1990. "The Incremental Information Content of Cash-flow Components." Journal of Accounting and Economics (May): 25-46.

41 Mood, A. M., F. A. Graybill, and D. C. Boes. 1974. Introduction to the Theory of Statistics. 3rd ed. New York: McGraw-Hill.

42 Nakano, I. 1972. "Noise and Redundancy in Accounting Communications." The Accounting Review (October): 693-708.

43 Neill, J. D., T. F. Schaefer, P. R. Bahnson, and M. E. Bradbury. 1991. "The Usefulness of Cash Flow Data: A Review and Synthesis.” Journal of Accounting Literature (vol. 10): 117-149. Neter, J. and W. Wasserman. 1974. Applied Linear Statistical Models. Homewood, IL: Richard D. Irwin, Inc.

Oliver, B. L. 1974. "The Semantic Differential: A Device for Measuring the Interprofessional Communication of Selected Accounting Concepts." Journal of Accounting Research (Autumn): 299-316. Osgood, C. E., G. J. Suci, and P. H. Tannenbaum. 1957. The Measurement of Meaning. Champaign, IL: University of Illinois Press.

47 Patell, J. M., and R. S. Kaplan. 1977. "The Information Content of Cash Flow Data Relative to Annual Earnings: Preliminary Tests.” Working paper, Stanford University.

48 Pendlebury, M. W. 1980. "The Application of Information Theory to Accounting for Groups of Companies." Journal of Business Finance \& Accounting (Spring): 105-117.

49 Rayburn, J. 1986. "The Association of Operating Cash flow and Accruals with Security Returns." Journal of Accounting Research (Supplement): 112-33.

50 Rohatgi, V. K. 1976. An Introduction to Probability Theory and Mathematical Statistics. New York: John Wiley and Sons. 
51 Ronen, J., and F. Falk. 1973. "Accounting Aggregation and the Entropy Measure: An Experimental Approach." The Accounting Review (October): 696- 717.

52 Schaefer, T., and M. Kennelley. 1986. "Alternative Cash Flow Measures and Risk-adjusted Returns." Journal of Accounting, Auditing, and Finance (Fall): 278-87.

53 Seber, G. A. F. 1977. Linear Regression Analysis. New York: John Wiley \& Sons.

54 Waymire, G. 1986. "Additional Evidence on the Accuracy of Analyst Forecasts Before and After Voluntary Management Earnings Forecasts." The Accounting Review (January): 129-142.

55 White, H. 1989. "Neural-Network Learning and Statistics." AI Expert (December): 48-52.

56 Wilson, G. P. 1986. "The Relative Information Content of Accruals and Cash Flows: Combined Evidence at the Earnings Announcement and Annual Report Release Date." Journal of Accounting Research (Supplement): 165-200.

57 Wilson, G. P. 1987. "The Incremental Information Content of the Accrual and Funds Components of Earnings after Controlling for Earnings." The Accounting Review (April): 293-322.

\section{ENDNOTES}

1. Syntactic information theory is concerned with surprise value, semantic information theory is concerned with meaning, and pragmatic information theory is concerned with value.

2. The messages related to these economic events are not signaled (reported) due to the nature of cash-flow accounting. Consequently, cash-flow reporting on a periodic basis may be characterized as introducing syntactic noise into financial reports. This syntactic noise obscures the signals of certain economic events, i.e., those economic events that are not reported.

3. Syntactics is concerned with the existence (or nonexistence) of a signal (Hyvärinen 1968). If an economic event is not signaled by an accounting system, then the accounting data generated by that accounting system is distorted by syntactic noise. Because of its nature, cash-flow accounting generates a high amount of syntactic noise.

4. See Bedford (1965) for a discussion of the use of discrete transactions to reflect continuous economic events.

5. Cash-flow data is defined in this study as cash and cash flows from operations.

6. This axiom equates predictive ability with value.

7. Fawcett and Downs (1986, vii) comment that ". . the paucity of recognizable theory in some disciplines is due to investigators' failure to be explicit about the theoretical components of their studies." It is possible that past studies examining the information content of accounting accruals and/or cash flows were based on unstated theories of accruals and/or cash flows. However, no previous study has explicitly expressed a formal theory of accounting accruals.

8. Semantic space was defined as a "Euclidian multidimensional region" (Haried 1972, 378). Orthogonal vectors in semantic space were represented by seven-point semantic scales that were defined by two contrasting adjectives, e.g., beneficial--adverse, tangible--intangible. The semantic scales were used to measure both distance and direction from the origin in semantic space.

9. Lebar $(1982,177)$ defined the objectives of corporate disclosure as ". . . completeness, qualification, specificity, verification, and references."

10. These groups were the American Institute of Certified Public Accountants, the American Association of Collegiate Schools of Business, the Financial Analysis Federation, the National Association of Securities Dealers, Corporate Financial Executives, the Investment Bankers' Association, and the American Banking Association.

11. One of the purposes of this study is to provide evidence of the value of accounting accruals in the external reporting environment. Because quarterly and annual financial statements are the most commonly issued external financial reports, the financial statement time frames used are quarterly and annual.

12. Neural networks, the forecasting technique used in this study, require relatively complete data to train 
properly. Expansion of the time period of interest in conjunction with the requirement of relatively complete data results in an unacceptable sample size. The three-year time period used in this study, 1986 to 1988 , is a compromise with respect to sample size and data completeness.

13. Similar measures of predictive accuracy have been used in several previous studies (Waymire 1986; Hassell and Jennings 1986; and Brown et al. 1987).

14. Although balance sheet accruals are the result of many periods of business activity, they represent potential future cash inflows and potential future cash outflows (FASB 1978, 20). Accordingly, they were used in the prediction of future cash flows from operations.

15. Only firms which used the cash-basis method of reporting on the SCFP for the entire period of interest were included in the sample.

16. Debt in current liabilities, income taxes payable, equity in net loss (earnings), and sale of property, plant, and equipment and sale of investments--loss (gain) were not examined for missing or zero values.

17. All of the data values of these firms were near zero, e.g., $\$ 100$.

18. Neural networks are computers or computer programs that are patterned after the brain. Consequently, they are composed of a large number of highly connected, simple processing elements. Similar to the brain, they learn from experience. Neural networks have been used successfully in numerous accounting studies including

19. See Etheridge, Sriram and Hsu (2000) for a brief description of backpropagation neural networks.

20. Backpropagation neural networks operate in a fashion similar to the stochastic approximation method and can be considered an approach to solving the least squares problem (White 1989).

21. See Judge et al. (1985) for a discussion of the estimated generalized least squares technique.

22. Asymptotic normality of $\mathrm{W}^{\prime}$ is a direct consequence of the central limit theorem and the theory of linear transformations of vector random variables (Seber 1977, 8-11; Mood et al. 1974, 195). Asymptotic normality of W" is guaranteed since D is a consistent estimator of D (Rohatgi 1976, 244).

23. See Kirk (1982) for a discussion of the Bonferroni procedure.

24. This statement directly relates to the sample of firms used in this study. The firms in this study are large, publicly-held corporations whose annual financial statements are subject to audits.

25. Unreliable accrual data may be distorted by syntactic noise, semantic noise, or both. An example of syntactic distortion would be errors or irregularities in accrual data. An example of semantic noise would be changes in accounting methods.

26. The inappropriate shifting of accruals from one period to another to smooth income is an example of syntactic noise. Changes in accounting methods to smooth income are examples of semantic noise. Audits may deter these income manipulations and, therefore, annual accrual data may be more reliable than quarterly accrual data. 